\section{Whatever Next?}

Much has been made of the creation of Materials Science \& Engineering as a legitimate academic discipline. Some discussions of the birth verge on the selfcongratulatory, while others almost seem to adopt a posture of shock. A particularly well-researched and mostly evenhanded history of the phenomenon can be found in Robert Cahn's book, The Coming of Materials Science (Pergamon, 2001). Naturally, I am completely unswayed in my opinion of this book by the role that Professor Cahn ascribes to the Materials Research Society in the creation of the new discipline.

Materials Science \& Engineering did not appear unheralded upon university campuses. The title is now in the later stages of becoming the "industry standard," within the United States at least, as the few remaining departments of Metallurgy, Ceramics, Mining, or whatever switch to the new moniker; but in every case, the change of name really only reflects a single event in an evolutionary continuum. My own baccalaureate degree (Bachelor of Metallurgy, no less!), though it was earned back in the mists of time, in a steel town like Sheffield, England, required almost as much study of ceramics, glasses, and polymers as it did of metals; so the seeds of Materials Science \& Engineering were already sprouting widely as long ago as the early 1970s.

As we celebrate (or bemoan) the coming of Materials Science \& Engineering, it is as well to consider the evolution of some other disciplines on university campuses. Evolution does not stop, after all, just because we have reached a point that particularly pleases us.

In the middle ages, a university gentleman (for ladies were not allowed) would be obliged to study the seven disciplines of the liberal arts, which are separated into two divisions. The lower division comprises grammar, rhetoric, and logic, and is known as the Trivium. The upper division comprises arithmetic, music, geometry, and astronomy, which together form the Quadrivium. Those of you burdened with the remnants of a classical education will understand the etymology of the terms Trivium and Quadrivium, and possibly find it interesting to note that the modern word "trivial" derives from
Trivium. As far as I know, nobody uses "quadrivial" as an opposite for "trivial," but those of you who would do so will be happy to know that another popular descriptor of learned work, "drivel," does not derive from Quadrivium, according to the Oxford English Dictionary.

And the Oxford English Dictionary, itself, was created at the great university in the 19th century, long after the seven

\section{Evolution does not stop... just because we have reached a point that particularly pleases us.}

disciplines of the liberal arts had been replaced by more specialized areas of study, and it was the lifelong project of Professor James Murray, who held a chair in Philology. You may repair to the OED if you need a definition of "philology," or else read an interesting account of the Dictionary's creation in The Professor and the Madman by Simon Winchester (HarperCollins, 1998). The point here is that philology, once a bastion of the academy, is now all but forgotten as a subject of advanced study.

Like philology, many subjects have come and gone again over the years. You can rely on finding many different subjects at most universities, but you will probably have a long search to find a place to study natural philosophy these days. Geography is largely gone from university catalogs, and the life-science duo of botany and zoology are giving way to molecular microbiology, genetics, biophysics, and a whole collection of other specialties. Scan the obituaries in the London Times and you are bound to come across people (mostly distinguished civil servants, if that is not an oxymoron) who studied "Greats" at Oxford. This is only an informal name for Literae Humaniores, or the great classical authors in Latin and Greek. You can still study Greats, but only at a university that places a particularly high value on tradition. British students, with no Empire left to manage after graduation, also now find it very hard to find places to study once-vital subjects such as Urdu.
So perhaps Materials Science \& Engineering is only a temporarily safe home for some of the academics in my audience. Some of them will enjoy the challenge of speculating about what might come next, while others may take comfort in the idea that change comes slowly. Evolution and geology operate on similar time scales, so too do academic evolution and campus construction, no? Well, perhaps it is not such a comforting thought after all: Geological time scales are wonderfully deceiving. When we are told that the Grand Canyon deepens and widens at a rate of a few millimeters a year, we imagine a slow, persistent, erosive process reminiscent of Chinese proverbs about water dripping on a stone, but a trip down the Colorado River after (or even during) a heavy rain reveals the truth. The Canyon changes its form not by a continuous process, but by a highly discontinuous one of occasional washouts and rockfalls. To be sure, these average out nicely, in the long term, but if you are unlucky enough to be present when an erosive "event" occurs, you run a pretty good risk of coming to harm. So it is with the evolution of academic disciplines. We like to believe in a slow process in which retiring senior faculty are replaced by young turks with new skills and approaches, but most of the real change in academia occurs in uncomfortable jolts, and usually when times are at their worst. Disciplines are created, either completely anew or by dividing up existing departments. Sometimes departments are merged; sometimes in a wonderful academic euphemism, they are retrenched. These fates usually befall units that fail to prepare appropriately for their future, just as rockfalls appear to have a selective effect on those who fail to anticipate them.

Change is inevitable. The subject matter of Materials Science \& Engineering will be unrecognizable to most of us 20 years from now if we are unfortunate enough to look at it with today's eyes. Those who regard this as a threat will probably try to resist change, but those who enjoy a little excitement will take part in the process of redefinition-and most likely do so by attending MRS meetings, I hope!

Alex KING 